\title{
Adaptation of Questionnaire on Online Gaming Addiction for University Students
}

\author{
Seyhan Bekir ${ }^{1} \quad$ Selami Yıldırım²
}

\begin{abstract}
The study is aimed to adapt the Online Gaming Addiction Questionnaire for university students. The research sample consists of 254 university students receiving education in Sakarya and İzmir provinces and playing online games. Three subscales, explaining $63.1 \%$ of the total variance, were obtained in compliance with the original scale via factor analysis. The analysis for criterion validity showed that, there is $59.7 \%$ positive correlation between the present research and that of Young's Questionnaire on Internet Addiction. Also, the scale's overall internal consistency coefficient was found as .93, and those of the "success", "inconveniences", and "economic gain" subscales were found as .93, .89, and .84 respectively. Application of test-retest resulted in a correlation coefficient of .86. The findings supported the validity and reliability of The Questionnaire on Online Gaming Addiction for University Students as a measurement tool.
\end{abstract}

Keywords: Online Gaming, Addiction, Validity, Reliability, Factor Analysis

\section{INTRODUCTION}

The history of gaming dates back to very ancient times. In the past, games like marbles, hide-and-seek and nine tiles could serve as good examples to popular games, however, the concept of "gaming" has changed a lot in the last decades, rendering these games obsolete (Öncel \& Tekin, 2015). Tablet pc and computer games are now what come to mind when it comes to gaming. These games' most distinctive feature is their violent content and their being addictive (Young, 1996). In the related literature no study on the relationship between the games in the past and addiction is encountered, however, numerous studies have been conducted on the relationship between modern games and addiction. Among these, Çakır, Ayas, and Horzum (2011) investigated gaming addiction among university students. Their findings indicated that male students displayed higher addiction levels as compared to female students, and no significant difference was found on the basis of the types of computer games and the students' school grades. The international literature involves gender-based studies with similar results as well (Ko, Yen, Chen, Chen, \& Yen 2005; McInroy \& Mishna, 2017). Karakoyun (2017) reported that, online gaming has a high potential to pose harm among university students. Balcı and Gülnar (2009) stated that $40.4 \%$ of the participating university students were internet addicts, and Karakoyun (2007) reported in their study performed on a sample of 401 university students that, online gaming had the highest arithmetic mean score among the intended uses of internet. In the present research, the portion of online gaming in internet usage is higher than the options such as reading news on the internet, surfing on the internet, chatting and using social networks (Instagram, Facebook, etc.). Recent statistical researches and academic studies reveal that gaming addiction among university students has shown an increasing trend, and is likely to increase in the future as well.

\footnotetext{
1 Ma, Sakarya University, Faculty of Education, seyhanbekir93@gmail.com

${ }^{2} \mathrm{Ma}$, Sakarya University, Faculty of Education, yldrmselami5@gmail.com
} 
This notion is further supported by the finding of a research performed in Turkey that, the number of people with internet access has substantially increased especially over the last decade. This finding was published by Turkish Statistical Institute (2016) by data no 21779. The findings of this research also show that the ratio of Turkish population with internet access has reached $80 \%$ in 2016 from 20\% in 2007 . The ratio of internet usage was reported as 33\% among 16-74 age group in 2007, whereas this ratio reached 65\% in 2016 (Research on the Use of Information Technologies among Household, 2016, Turkish Statistical Institute News Bulletin, 21779). This indicates that, eight houses out of ten have internet access. The related literature involves studies with similar results. According to the June data of Internet World Stats, 51.7 of the World population use internet. This ratio is $80.02 \%$ in Europe, $88.1 \%$ in North America, and 46.7\% in Asia (IWS, 2017). An individual is considered to pass the first stage of online gaming addiction by becoming an addict as a result of problematic internet usage for long periods so as to hinder his/her works and relationship with the environment. The second stage comes with spending days, even months with internet and online gaming (Kaya, 2013). Statistical research results show that $80,2 \%$ of European population have internet access, and all these people have the potential to become an internet or online gaming addict. This forecast is based on the assumption that easy and costless access to internet is likely to increase the addiction among individuals, particularly university students. It is also reported in a national research that, online gaming addiction poses a serious risk for university students (Kaya, 2013).

Addiction is defined as the inability to avoid or control a behavior or the use of a substance (Egger \& Rauterberg, 1996). Karaman and Kurtoğlu (2009) addressed addiction at two main levels, namely drug or substance abuse and addictive behavior. Caffeine, tea and smoking addiction stand for the addiction to a substance. The other type of addiction relates to repetition of a behavior at an abnormal frequency which in turn induces physical and psychological issues and challenges about adapting to the environment (Karaman \& Kurtoğlu, 2009). According to Kim and Kim (2002), addiction does not only relate to smoking, alcohol and substance addiction, but also to behavioral addictions such as computer addiction, television addiction and internet addiction.

The concept of internet addiction was firstly introduced by Young (1996) who also established the first diagnosis criteria and stated that internet leads to addiction just like gambling. Internet addicts also display various impulse and control disorders (Cited in Arısoy, 2009). Internet addiction is also defined as spending long periods in the internet and being unable to control oneself (Chak \& Leung, 2004). According to Peltoniemi (2012), internet addiction has several sub-branches. One of these sub-branches can be considered as online gaming addiction. In the national literature, Kaya (2013) defined online gaming addicts as individuals that spend days, even weeks by their computers to achieve a level in a game. Madran and Çakılcı (2014) proposed that, online gaming can be associated with internet and computer addiction. As also revealed by Balc1 and Gülnar's (2009) and Karakoyun's (2017) studies, university students playing online games are under an important risk.

This research, performed on university students, is important for determination of online gaming addiction which has a major effect on their university lives and mental health. Reportedly, there is an increasing trend towards online gaming in Turkey, which has adverse effects on individuals' mental health and social lives. As also reported in a conference organized by Yeşilay (The Green Crescent) and Information Technologies Institution, a requirement has arisen to have a better understanding of 
Technology Addiction, which is regarded as a modern type of addiction. The ultimate goal has become prevention of addiction among university students before it affects their academic lives and causes them to quit university education. Collective use of this scale, adopted for university samples, along with the other psychological scales holds great importance for providing a better insight into online gaming addiction and giving an early response. No scale for online gaming addiction for university students was encountered in the related national literature. In this regard, the present research was performed with a view to adapt the scale for university students.

\section{METHOD}

In this study, screening method among quantitative research methods was used (Altunişik, Coşkun, Bayraktaroğlu and Yildirim, 2007). Screening method is applied for data collection from a group of individuals to determine their specific attributes. Acquisition of data from very large samples is one of the important advantages of screening researches (Büyüköztürk, Çakmak, Akgün, Karadeniz, \& Demirel, 2016).

\section{Study Group}

The study group consists of 254 voluntary university students receiving education in the 1st, 2nd, 3rd and 4th grade of a group of universities in Turkey as of 2016-2017 academic year. 188 of the participating individuals are male, and 66 are female. The students constituting the sample were selected using random sampling method. These students voluntarily participated in the research.

\section{Data Collection Tools}

\section{Questionnaire on Online Gaming Addiction}

The scale was developed by Kaya in 2013 for high school stu-dents. The scale consists of 21 items (Sample statement: I feel attached to my online gaming group). The scale is of likert- 5 type ( $1=$ absolutely disagree, $2=$ disagree, $3=$ indecisive, $4=$ agree, $5=$ absolutely agree), and has three subscales of online gaming addiction scale (inconveniences, success, economic gain). The scale's reliability was examined with Spearman-Brown and Cronbach's Alpha and test-retest methods. Its validity was calculated using Exploratory Factor Analysis (EFA). The EFA results revealed a structure with three factors having $58.55 \%$ total variance. The highest factor is .876 and the lowest is .606 . The reliability analysis of Questionnaire on Online Gaming Addiction shows that Cronbach's Alpha coefficient of the scale explains .91 of the overall scale. Spearman-Brown reliability coefficient was calculated as .94 for overall scale. The consent of the researcher who developed the scale was received prior to the present research. The items that lead to online gaming addiction were analyzed and they were found suitable on the basis of related studies (Müezzin, 2015; Ko, Yen, Chen, Chen, \& Yen, 2005; Mehroof \& Griffiths, 2010; Young, 2009). Verbal feedbacks of the volunteering participants also supported this decision.

\section{Young Internet Addiction Test}

This test was initially developed by Young in 1998, and adopted into Turkish by Balta and Horzum in 2008. The reliability and validity of the test was re-examined by Kutlu, Savc1, Demir, and Aysan in 2016. This test was used for criterion validity with a view to explain the results in an associated manner as 
also stated by Madran and Çakılcı (2014). This test involves 12 items (sample statement: How often do you stay on internet more than you have planned). The scale is of likert-5 type and involves the following options: “Always (5), often (3), sometimes (3), seldom (2), never (1)". After EFA, the scale was found to have a single factor ex-plaining the $39.52 \%$ of overall scale. The following results were found after confirmatory factor analysis $(\mathrm{CFA}): \chi 2=144.93, \mathrm{DF}=52, \mathrm{RMSEA}=0.072, \mathrm{RMR}=0.70, \mathrm{GFI}=0.93$, AGFI $=0.90, \mathrm{CFI}=0.95$ and $\mathrm{IFI}=0.91$. The factor loading of Young's Internet Addiction Test-Short Form (YIAT-SF) varies be-tween 0.33-0.67. The Cronbach's Alpha reliability coefficient was found as .91 for university stu-dents. None of the scale items was subject to reverse scoring.

\section{Data Analysis}

The reliability of Questionnaire on Online Gaming Addiction was tested using Cronbach's Alpha, and its compliance with factor analysis was evaluated with Kaiser-Meyer-Olkin (KMO) test. It was tested whether the scale comprised of three structures as Gain, Inconveniences and Success using exploratory factor analysis. Factor analysis is used to evaluate a specific quality or structure through collective evaluation of the scale items (Doğan \& Başokçu, 2010). The reliability of the scale was also tested with test-retest through application on 50 university students with 2 weeks interval. Two scales were applied on 50 university students for criterion validity as well. The data obtained from the research were evaluated using SPSS 20 software.

\section{FINDINGS}

Exploratory Factor Analysis (EFA): EFA was used to evaluate the factor structure after the application of the scale on university students. Kaiser-Meyer-Olkin (KMO) test was used for testing the factor analysis suitability of the number of data. KMO value was calculated as .929 . This value is indicative of the normality and suitability of the obtained scores. Analysis results explained $63.128 \%$ of the total variance and it was accordingly verified that the scale consisted of three factors. The factor loadings of the inconveniences sub-scale varied between .59 and .83 , those of the success sub-scale varied between .81 and .58 , and those of the economic gain sub-scale varied between .82 and .64 , respectively. The factor loadings are shown in Table 1.

\section{Table 1}

The Factor Loadings of the Questionnaire on Online Gaming Addiction for University Students

\begin{tabular}{|c|c|c|c|}
\hline & Inconveniences & Success & Economic Gain \\
\hline s5 & ,839 & & \\
\hline s21 & ,783 & & \\
\hline s1 & ,764 & & \\
\hline s17 &, 746 & & \\
\hline s7 & ,742 & & \\
\hline
\end{tabular}




\begin{tabular}{llll} 
s14 &, 650 & & \\
s3 &, 649 & & \\
s12 &, 619 &, 818 & \\
s9 &, 599 &, 810 & \\
s19 & &, 762 & \\
s2 & &, 726 & \\
s8 & &, 720 & \\
s18 & &, 705 & \\
s13 & &, 608 &, 826 \\
s16 & &, 587 &, 605 \\
s10 & & & \\
s4 & & & \\
s11 & & & \\
s15 & & & \\
s6 & s20 & & \\
\hline
\end{tabular}

\section{Criterion-related Validity}

QOGA (Questionnaire on Online Gaming Addiction) and YIAT (Young's Internet Addiction Test) were applied on 50 university students to evaluate their relationship and the criterion validity of the questionnaire. These data were examined using Pearson Correlation Analysis. As a result, a positive correlation was detected between QOGA and YIAT $(r=.59 .7, p<.000)$, which is indicative of a significant relationship.

\section{Reliability}

The reliability of the scale was calculated with internal consistency, and test-retest methods. The internal consistency coefficient of the scale was found as .93 using Cronbach Alpha test. The Cronbach's Alpha value of the inconveniences sub-scale was found as .93 , that of the success subscale was found as .89 , and that of the economic gain subscale was found as .84. Also, the items factor loadings varied between, 595 and, 839. The scale was applied on 50 students with an interval of two weeks to evaluate its testretest reliability. The result of test-retest was found as .86 . This result reveals that the scale yields similar results with passing time. 


\section{DISCUSSION}

This study was carried out in an attempt to adapt the Online Gaming Addiction Scale developed by Kaya (2013) for high school students for university students. The validity and the reliability of the adapted scale was also examined through analyses. Exploratory Factor Analysis (EFA) was used to examine the structural validity of the scale. Internet Addiction Test developed by Young (1998) and adapted for university students by Kutlu, Savc1, Demir and Aysan (2016) was used for criterion validity. Cronbach's Alpha method was used to evaluate its reliability. According to the analysis results, the scale consists of 21 items and 3 factors.

As reported by Büyüköztürk (2010), the result of exploratory factor analysis should be more than $41 \%$, and the factor loadings should be higher than .32 , as a requirement for conducting criterion validity of a newly developed or adapted scale. QOGA's exploratory factor analysis results show that, $62.9 \%$ of the total variance is explained with three factors. The item factor loadings of QOGA are .58 and .82, respectively. The correlation between QOGA and Young's Internet Addiction test was sought to determine QOGA's criterion validity, and a positive correlation of .58 was found accordingly. The similarity between two scales is mainly attributable to their similar characteristics. The most effective factor is considered to be success factor as also supported by other studies on internet addiction and online gaming addiction (Balcı \& Gülnar, 2009; Chen \& Peng, 2008; Çakır, Ayas, \& Horzum, 2011; Esen \& Siyez, 2011; Günüç \& Kayri, 2010; Kaya, 2013; Matthews \& Schrum, 2003; Ng \& Wiemer-Hastings, 2005; Şenormanc1 \& Sungur, 2010).

QOGA is considered to have a great importance in terms of university students' mental health, and for gaining more insight into the online gaming addiction which is a sub-branch of technology addiction. Various psychological variables can be analyzed with the scale and psycho-educational interventions can be performed to avoid addiction through investigation of the related variables. The study population involves university students in a specific number of cities. Limited numbers of studies have been performed on addiction of university students. Also, from a socio-cultural point of view, these students have a wide variety of ethnic origins and other attributes. As a result, the findings of validity and reliability studies Show that, the present scale can be used as a valid and reliable measurement tool to evaluate university students' addictive behaviors. The scale's study group is limited to university students. Further contributions can be made through investigations on different and larger samples. Various other items can be included to improve the validity and reliability in line with today's rapidly developing technology. This scale can be also used as a means for coping with online gaming addiction through its collective use with other psychological variables.

\section{REFERENCES}

Altunişik, R., Coşkun, R., Bayraktaroğlu, S., \& Yildirim, E. (2007). Sosyal bilimlerde araştırma yöntem-leri. Sakarya Yayıncilık, Sakarya, 226.

Arısoy, Ö. (2009). İnternet bağımlılığı ve tedavisi. Psikiyatride güncel yaklaşımlar, 1(1), 55-67

Balcı, Ş., \& Gülnar, B. (2009). Üniversite öğrencileri arasında internet bağımlılığı ve internet bağımlılarının profili. Selçuk Üniversitesi İletişim Fakültesi Akademik Dergisi, 6(1), 5-22. 
Büyüköztürk, Ş., Çakmak, E. K., Akgün, Ö. E., Karadeniz, Ş., \& Demirel, F. (2016). Bilimsel araştırma yöntemleri. Ankara: Pegem Akademi

Çakır, Ö., Ayas, T., \& Horzum, M. B. (2011). Üniversite öğrencilerinin internet ve oyun bağımlılıklarının çeşitli değişkenlere göre incelenmesi. Journal of Faculty of Educational Sciences, 44(2), 95-117.

Chak, K., \& Leung, L. (2004). Shynessandlocus of control as predictors of internet addiction and internet use. CyberPsychology \& Behavior, 7(5), 559-570.

Chen, Y. F., \& Peng, S. S. (2008). University students' Internet use and its relationships with academic performance, interpersonal relationships, psychosocial adjustment, and self-evaluation. CyberPsychology \& Behavior, 11(4), 467-469.

Doğan, N., \& Başokçu, T. O. (2010). İstatistik tutum ölçeği için uygulanan faktör analizi ve aşamalı kümeleme analizi sonuçlarının karşılaştırılması. Eğitimde ve Psikolojide Ölçme ve Değerlendirme Dergisi, 1(2), 65-71.

Egger, O., \& Rauterberg, M. (1996). Internet behavior and addiction. Semester thesis (Swiss Federal Institute of Technology, Zurich, 1996).

Esen, E., \& Siyez, D. M. (2011). An investigation of psycho-social variables in predicting internet addiction among adolescents. Turkish Psychological Counseling and Guidance Journal, 4(36), 127-138.

IWS, 2017. İnternet user in the world by geocrapic region. Retrieved 12.04.2018 from http://www.internetworldstats.com/stats.htm.

Karakoyun, F. (2017). Öğretmen adaylarının internet bağımlılık düzeylerinin incelenmesi: Dicle üniversitesi örneği. Elektronik Sosyal Bilimler Dergisi, 16(64), 1140-1149.

Karaman, M. K., \& Kurtoğlu, M. (2009). Öğretmen adaylarının internet bağımlılığı hakkındaki görüşleri. Akademik Bilişim, 11(13), 641-650

Kaya, A. B. (2013). Çevrimiçi oyun bağımlılığı ölçeğinin geliştirilmesi: Geçerlik ve güvenirlik çalışması, Master's thesis. Gaziosmanpaşa Üniversitesi, Eğitim Bilimleri Enstitüsü.

Kim, S., \& Kim, R. (2002). A study of internet addiction: Status, causes, and remedies. Journal of Korean Home Economics Association English Edition, 3(1), 1-19.

Ko, C. H., Yen, J. Y., Chen, C. C., Chen, S. H., \& Yen, C. F. (2005). Gender differences and related factors affecting online gaming addiction among Taiwanese adolescents. The Journal of nervous and mental disease, 193(4), 273-277.

Kutlu, M., Savci, M., Demir, Y., \& Aysan, F. (2016). Young İnternet Bağımlılı̆̆ı Testi Kısa Formunun Türkçe uyarlaması: Üniversite öğrencileri ve ergenlerde geçerlilik ve güvenilirlik çalışması. Anadolu Psikiyatri Derg, 17(Supplement 1), 69-76.

Madran, D., \& Çakılcı, F. (2014). Çok oyunculu çevrimiçi video oyunu oynayan bireylerde video oyunu bağımlılığı ve saldırganlık. Anadolu Psikiyatri Dergisi, 15, 99-107.

Matthews, D., \& Schrum, L. (2003). High-speed Internet use and academic gratifications in the college residence. The Internet and Higher Education, 6(2), 125-144. 
McInroy, L. B., \& Mishna, F. (2017). Cyberbullying on online gaming platforms for children and youth. Child and Adolescent Social Work Journal, 34(6), 597-607.

Mehroof, M., \& Griffiths, M. D. (2010). Online gaming addiction: the role of sensation seeking, selfcontrol, neuroticism, aggression, state anxiety, and trait anxiety. Cyberpsychology, behavior, and social networking, 13(3), 313-316.

Müezzin, E. (2015). An investigation of high school students' online game addiction with respect to gender. Turkish Online Journal of Educational Technology-TOJET.

Ng, B. D., \& Wiemer-Hastings, P. (2005). Addiction to the internet and online gaming. Cyberpsychology \& behavior, 8(2), 110-113.

Öncel, M., \& Tekin, A. (2015). Ortaokul öğrencilerinin bilgisayar oyun bağımlılığı ve yalnızlık durumlarının incelenmesi. İnönü Üniversitesi Eğitim Bilimleri Enstitüsü Dergisi, 2(4), 7-17.

Peltoniemi, T. (2002, March). Net addiction in Finland. In First prevent conference of telematics in addic-tion prevention, Athens, Greece.

Şenormanc1, Ö., Konkan, R., \& Sungur, M. Z. (2010). İnternet bağımlılığı ve bilişsel davranışçı tera-pisi. Psychiatry, 11, 261-268.

TÜIK,(2016). Hanehalkı bilişim teknolojileri kullanım araştırması. Retrieved 27.06.2017 from http://www.tuik.gov.tr/PreHaberBultenleri.do?id=21779.

Young, K. (2009). Understanding online gaming addiction and treatment issues for adolescents. The American Journal of Family Therapy, 37(5), 355-372.

Young, K. S. (1996). Psychology of computer use: XL. Addictive use of the Internet: a case that breaks the stereotype. Psychological reports, 79(3), 899-902.

Young, K. S. (1998). Internet addiction: The emergence of a new clinical disorder. Cyberpsychology $\mathcal{E}$ behavior, 1(3), 237-244. 